\title{
Wild Asian elephant Elephas maximus population in Salakpra Wildlife Sanctuary, Thailand
}

\author{
Rattanawat Chaiyarat ${ }^{1, *}$, Namphung Youngpoy ${ }^{1}$, Prawut Prempree ${ }^{2}$ \\ ${ }^{1}$ Wildlife and Plant Research Centre, Faculty of Environment and Resource Studies, Mahidol University, Phuttamonthon, \\ Nakhon Pathom Province 73170, Thailand \\ ${ }^{2}$ Salakpra Wildlife Sanctuary, Department of National Parks, Wildlife and Plant Conservation, Mueang District, \\ Kanchanaburi Province 71000, Thailand
}

\begin{abstract}
The population of wild Asian elephants Elephas maximus is declining worldwide; therefore, understanding the dynamics of the remaining population is critical for effective conservation. We monitored the population and distribution of elephants in Salakpra Wildlife Sanctuary, Thailand between May 2010 and March 2011. Using 32 camera trap locations and 1391 trap nights, we recorded 882 elephant photos. A total of 180 individuals were identified in the photos and classified as follows: 55 adult males, 60 adult females, 11 sub-adult males, 17 sub-adult females, 18 juveniles, and 19 calves. The age structure ratio (based on adult females) was $0.9: 1.0: 0.2: 0.3: 0.3: 0.4$, and the ratio of reproductive ability between adult females, juveniles, and calves was $1.0: 0.3: 0.3$. The ratio between adult females and infants was highest in areas containing a high concentration of salt licks, which could indicate that salt licks are a keystone resource for wild Asian elephants.
\end{abstract}

KEY WORDS: Wild Asian elephant - Age structure - Habitat management • Conservation • Population monitoring

\section{INTRODUCTION}

The continuous destruction of forested areas in Asia has had a negative impact on wildlife, particularly Asian elephants Elephas maximus. As a consequence, the population of wild elephants has declined from estimates of 41410 to 52345 individuals in 2003 (Sukumar 2003) to between 25600 and 32750 individuals in 2006 (WWF 2006). Elephants are large mammals that live in herds and have a pastoral lifestyle; these are characteristics that affect the land as well as other animal species (Sarker \& Røskaft 2010). Currently, Asian elephants are classified as Endangered in all countries where the species occurs (IUCN 2013). Thailand is the center of wild elephant distribution in Southeast Asia, and its borders represent potentially important transboundary areas linking the elephant populations of Thailand with those

\footnotetext{
${ }^{*}$ Corresponding author: rattanawat.cha@mahidol.ac.th
}

of the neighboring countries. In Thailand, population estimates for elephants range from 3000 to 3500 individuals (Srikrachang 2003). Considered an important umbrella, keystone, and seed-dispersing species (Campos-Arceiz \& Blake 2011), elephants may act as ecosystem engineers that support the biodiversity of the tropical rainforest by maintaining habitat gaps. However, the continuing loss of primary forests has reduced their ecosystem engineer function (Matsubayashi et al. 2006).

Camera traps can be effective tools for the documentation of wildlife (Rowcliffe \& Carbone 2008). This technology is an unobtrusive method for animal observation in any habitat (Silveira et al. 2003) and has been successfully used for individual identification of large mammal species (Lyra-Jorge et al. 2008). For example, camera traps appropriately estimated (with a small error) African elephant populations

() The authors 2015. Open Access under Creative Commons by Attribution Licence. Use, distribution and reproduction are unrestricted. Authors and original publication must be credited. 
using shoulder height as an indicator of age (Della Rocca 2007). Similarly, Varma et al. (2006) used camera traps to study the population dynamics of elephants in southern India.

In Thailand, elephants are distributed within protected areas, but their population status is not fully known (Srikrachang 2003). Salakpra Wildlife Sanctuary is one of the protected areas in the Western Forest Complex. The estimated elephant population ranges from 150 to 200 individuals (Srikrachang 2003). There has been rapid economic development within the Western Forest Complex, such as the construction of the Srinakarin and Thathungna Dams, roads, human settlements and agricultural activities, and the resulting habitat fragmentation has led to isolated populations of elephants (Pattanavibool et al. 2004). Habitat loss and fragmentation can lead to loss of genetic diversity (Kongrit et al. 2008) and reduce the population's carrying capacity potential. Although the size of the elephant population in Salakpra Wildlife Sanctuary has been evaluated (Srikrachang 2003), to our knowledge no studies have examined the population structure. In this study, we aimed to estimate the population size, age structure, and distribution of elephants in Salakpra Wildlife Sanctuary using camera traps. We also provide practical guidelines for the management of the elephants at that site.

\section{MATERIALS AND METHODS}

\section{Study area}

The study was carried out in the Salakpra Wildlife Sanctuary (14ㅇ' $8^{\prime} 37.09^{\prime \prime}$ N, 99 $\left.20^{\prime} 33.514^{\prime \prime} \mathrm{E}\right)$, an area of $\sim 860 \mathrm{~km}^{2}$ in Mueang, Bo Phloi, Si Sawat, and Nong Prue districts, Kanchanaburi Province, Thailand (Fig. 1). Elevation in the area ranges between 700 and $1000 \mathrm{~m}$ above sea level. The average temperature is $28^{\circ} \mathrm{C}$, with an average rainfall of $1071 \mathrm{~mm} \mathrm{yr}^{-1}$. The area consists of mixed deciduous forest $(60 \%)$, dry dipterocarp forest (30\%), and disturbed areas $(10 \%)$. The dominant plant species in the Sanctuary are Lagerstroemia tomentosa, Terminalia alata, T. triptera, T. bellirica, and Afzelia xylocarpa (Salakpra Wildlife Sanctuary 2011).

\section{Camera trap survey}

A preliminary survey for elephant signs was carried out in each of the study zones by walking, examining all available trails, water sources, natural licks, and forest types. All elephant signs were plotted in a Geographic Information System (GIS) along with associated details of elevation, slope, and forest type (Wang

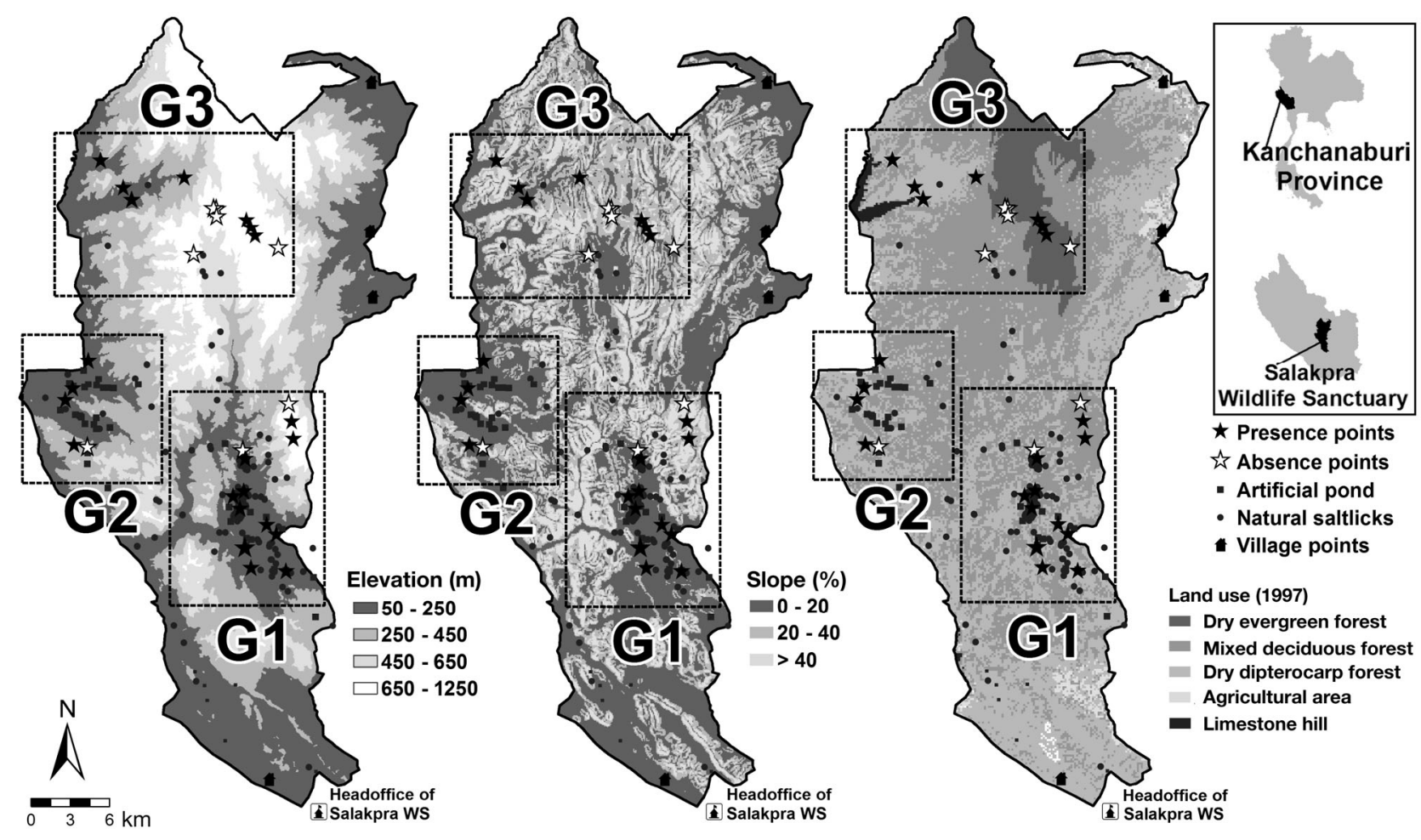

Fig. 1. Average elevation, slope, forest type and the occurrence of wild Asian elephants Elephas maximus in the Salakpra Wildlife Sanctuary, Thailand. G1: Thung Salakpra; G2: Mong Krathae; G3: Huai Mae Lamun 
\& Macdonald 2009). Camera trap locations were selected based on where elephant tracks were detected during the preliminary survey. For example, during the dry season elephants tend to be concentrated near water sources, and thus large water sources are suitable for direct counts of elephant populations (Wanghongsa 2004). Therefore, water sources within our study site were a major location for camera trap placement (Varma et al. 2006), followed by natural licks and wildlife trails (Rovero \& Marshall 2009), which are also frequently visited by elephants.

A total of 12 MOULTRIE ${ }^{\circledR}$ camera traps (model I40; Moultrie Feeders) were rotated among 32 trapping stations, with locations changed every $15 \mathrm{~d}$. Each trap station was set with 2 cameras facing each other, positioned to photograph both asymmetrical flanks of the elephant to ensure positive identification (Soisalo \& Cavalcanti 2006). Camera traps were mounted on trees approximately $0.75 \mathrm{~m}$ above the ground (Rowcliffe et al. 2008), with distances between traps ranging from 1 to $3 \mathrm{~km}$. Camera traps operated continuously for $24 \mathrm{~h}$ with a shooting interval of $1 \mathrm{~min}$. The resolution of the pictures was $1648 \times 1236$ pixels. Camera ID, time, date, and temperature were also recorded for each exposure and were stamped on the photographs.

\section{Population density}

The photographs obtained from the camera traps were used to identify and record the location, forest type, date, time, sex, and age of each animal. We also recorded obvious distinguishing morphological features and basic body dimensions to differentiate among individuals (Goswami et al. 2012). Only photographs with sufficient quality, clarity, and position of the elephant in the frame were used for identification (Varma et al. 2006). Here, quality refers to how usable a picture is for age and sex classification; clarity indicates whether the elephant was 'captured' in good light, the flash reached the object, and the picture is in focus and not over or under-exposed; and position refers to the occurrence of the elephant within an 'optimal distance' from the camera, and whether all or most of the head and tail of of the individuals is visible. Thus, even if a picture is of good quality, the information captured in the picture may not be adequate and it would therefore not be usable. Elephants in the photographs were classified as adults, sub-adults, juveniles, or calves using approximate height as recommended by Arivazhagan \& Sukumar (2008) and Ashokkumar et al. (2010).
Adults and sub-adults were further classified as male or female by their distinctive secondary sex characteristics; these characteristics were not apparent in the juveniles and calves. We defined the age structure as the ratio between adult males, adult females, sub-adult males, sub-adult females, juveniles, and calves; reproductive ability was the ratio of age structure between adult females (including sub-adult females), juveniles, and calves. Male elephants living outside the herd were classified as solitary males.

Capture history was used to generate capture frequencies of identified individuals. Data were recorded in an $x$ matrix consisting of $i$ elephants in rows and $t$ trapping occasions in columns, assuming a value of either ' 0 ' if the individual was not photographed or a ' 1 ' if it was photographed. The capture histories of individual elephants were used in the framework of capture-recapture theory to estimate capture probabilities and population size using the computer program MARK (White \& Burnham 1999). Based on the capture-recapture analysis, 4 models were distinguished: (1) $\mathrm{M}(0)$, which assumes that there is no heterogeneity in capture probability and that capture probability is constant across capture occasions, (2) $\mathrm{M}(t)$, which allows capture probabilities to vary among capture occasions but assumes no heterogeneity in capture probability, (3) M(h), which allows for heterogeneity in capture probabilities among individuals, and (4) $\mathrm{M}(b)$, which allows for the capture probabilities of individuals to be a function of their previous capture history (see Table 1). Determined deviance information criterion (DIC) values ranged between 21.30 and 21.73. Based on White et al. (1982), the model with the lowest DIC should be selected as the population estimate.

The population density of elephants was calculated as follows:

Crude density (ind. $\mathrm{km}^{-2}$ ) $=$ total no. ind. / total area $\left(\mathrm{km}^{2}\right)$

while the relative abundance index (RAI) for elephants in each zone was calculated as:

$$
\begin{gathered}
\mathrm{RAI}=(\text { no. independent photographs at all locations } \\
\times 100) / \text { total no. trap-nights }
\end{gathered}
$$

RAI increased when elephants were at high densities.

\section{Habitat use}

Habitat utilization was defined as the presence or absence of elephants in the habitat types of all camera trap locations. Average elevation was classified 
as lowland (50 to $250 \mathrm{~m}$ ), foothills (250 to $450 \mathrm{~m}$ ), mountains (450 to $650 \mathrm{~m}$ ), and highlands (650 to $1250 \mathrm{~m})$. Slope was classified as 0 to $20 \%$, 20 to $40 \%$, and $>40 \%$ (Feng et al. 2010). Forest type was classified as mixed deciduous, dry deciduous dipterocarp, or dry evergreen forest (Salakpra Wildlife Sanctuary 2011). Threat factors such as poachers, hunting dogs, and domestic cattle were recorded from the camera trap photos.

The locations of all cameras were recorded using a global positioning system (GPS) unit. Topographic data were obtained from WEFCOM (2004), and ArcView v.12 (ESRI 2007, www.esri.com/index.html) was used to create the maps. Relative frequency (RF), used to estimate the distribution of the elephants, was calculated for all camera trap locations as:

$\mathrm{RF}=$ No. camera locations that captured photographs $\times 100$ / total camera locations

\section{Statistical analysis}

A 1-way ANOVA was used to compare population structure in different areas. The coefficient of correlation was used to analyze the relationship between the population structure and water sources, natural licks, elevation, slope, forest types, and threat factors using SPSS v.17.0 (SPSS Inc.). Differences between population structure and environmental factors were considered significant at $\mathrm{p}<0.05$.

\section{RESULTS}

\section{Population density}

A total of 180 individuals were identified from 882 photographs at 23 camera trap sites in Salakpra Wildlife Sanctuary. Based on this information, we determined that the $\mathrm{M}(b)$ model, which estimated a population size $( \pm \mathrm{SE})$ of $181.20 \pm 1.51$ individuals, was the most suitable (Table 1). The crude density of
Table 1. Model selection statistics using the closed population estimation model type on wild elephant Elephas maximus capture-recapture data from the Salakpra Wildlife Sanctuary, Thailand. For a definition of $\mathrm{M}(0), \mathrm{M}(t), \mathrm{M}(h)$, and $\mathrm{M}(b)$ see 'Materials and methods; Population density'. DIC: deviance information criterion; $\mathrm{N}$ : population size; $\mathrm{SD}$ : standard deviation

\begin{tabular}{|lccc|}
\hline Model & DIC & N & SE \\
\hline$M(0)$ & 21.73 & 181.48 & 2.12 \\
$M(t)$ & 21.31 & 181.57 & 3.24 \\
$M(h)$ & 21.45 & 181.86 & 2.80 \\
$M(b)$ & 21.30 & 181.20 & 1.51 \\
\hline
\end{tabular}

wild Asian elephants in Salakpra Wildlife Sanctuary was 0.21 ind. $\mathrm{km}^{-2}$. The population was classified as consisting of 55 adult males, 60 adult females, 11 sub-adult males, 17 sub-adult females, 18 juveniles, and 19 calves, with a ratio of $0.9: 1: 0.2: 0.3: 0.3: 0.4$ using the adult female as a reference. The ratio of reproductive ability between adult females (including sub-adult females), juveniles, and calves was $1: 0.3: 0.3(F=0.778, \mathrm{df}=2, \mathrm{p}=0.46)$ (Table 2$)$.

\section{Distribution}

Animals were separated into 3 distinct groups based on camera trap locations (Fig. 1): Group 1, Thung Salakpra, located at the center of the Salakpra Wildlife Sanctuary, contained 123 individuals; Group 2, Mong Krathae, located near Ban Mong Krathae and Ban Koh Buk in the western part of the Salakpra Wildlife Sanctuary consisted of 30 individuals; and Group 3, Huai Mae Lamun, located near Huai Mae Lamun and Huai Mae Plasoi in the northern part of the Sanctuary contained 27 individuals.

Most elephants were found in the lowland areas (50\%), while only a solitary male (16\%) was found in the highlands. The number of elephants decreased as elevation increased $(r=-0.18, p=0.02)$. Elephants were found in all slope types, but their presence decreased as the slope increased $(r=-0.10, p=0.18)$.

Table 2. Ratio of age classes and reproductive rate of each geographical group of wild Asian elephants Elephas maximus in the Salakpra Wildlife Sanctuary, Thailand, using adult females as a reference. AM: adult male; AF: adult female; SM: sub-adult male; SF: sub-adult female; JU: juvenile; CA: calf

\begin{tabular}{|c|c|c|c|c|c|c|c|c|c|c|c|c|}
\hline \multirow{2}{*}{ Group } & \multicolumn{6}{|c|}{-Age structure ratio } & \multicolumn{3}{|c|}{ Reproductive ratio } & \multirow[t]{2}{*}{$F$} & \multirow[t]{2}{*}{ df } & \multirow[t]{2}{*}{$\mathrm{p}$-value } \\
\hline & $\mathrm{AM}$ & $\mathrm{AF}$ & SM & $\mathrm{SF}$ & $\mathrm{JU}$ & $\mathrm{CA}$ & $\mathrm{AF}+\mathrm{SF}$ & $\mathrm{JU}$ & $\mathrm{CA}$ & & & \\
\hline Thung Salakpra & 0.9 & 1 & 0.2 & 0.2 & 0.4 & 0.4 & 1 & 0.4 & 0.4 & 0.937 & 10 & 0.50 \\
\hline Mong Krathae & 1.0 & 1 & 0.1 & 0.6 & 0.2 & 0.4 & 1 & 0.2 & 0.4 & 0.944 & 2 & 0.40 \\
\hline Huai Mae Lamun & 0.8 & 1 & 0.1 & 0.3 & 0.2 & 0.1 & 1 & 02 & 0.1 & 1.590 & 4 & 0.21 \\
\hline Total & 0.9 & 1 & 0.2 & 0.3 & 0.3 & 0.4 & 1 & 0.3 & 0.3 & 0.778 & 2 & 0.46 \\
\hline
\end{tabular}


Table 3. Environmental factors and the occurrence of wild Asian elephants Elephas maximus in Salakpra Wildlife Sanctuary, Thailand. Times: no. of times an individual was photographed; gaps indicate data not available

\begin{tabular}{|c|c|c|c|c|c|c|c|c|}
\hline $\begin{array}{l}\text { Environmental } \\
\text { factor }\end{array}$ & $\overline{\text { Times }}$ & $\begin{array}{l}\text { Presence- } \\
\text { Frequency }(\%)\end{array}$ & Times & $\begin{array}{l}\text { Absence }- \\
\text { Frequency (\%) }\end{array}$ & $\begin{array}{l}\text { Relative frequency } \\
\text { of occurrence }(\%)\end{array}$ & $F$ & df & $\mathrm{p}$-value \\
\hline $\begin{array}{l}\text { Habitat use } \\
\text { Waterholes } \\
\text { Natural licks } \\
\text { Trails }\end{array}$ & $\begin{array}{c}7 \\
10 \\
6\end{array}$ & $\begin{array}{c}100 \\
90.9 \\
42.9\end{array}$ & $\begin{array}{l}0 \\
1 \\
8\end{array}$ & $\begin{array}{c}- \\
9.1 \\
57.1\end{array}$ & $\begin{array}{l}22 \\
31 \\
19\end{array}$ & 1.979 & 2 & 0.14 \\
\hline Total & 23 & & 9 & & & $\mathrm{r}$ & & p-value \\
\hline $\begin{array}{l}\text { Elevation (m) } \\
50-250 \\
250-450 \\
450-650 \\
650-1250\end{array}$ & $\begin{array}{l}16 \\
2 \\
- \\
5\end{array}$ & $\begin{array}{c}94.1 \\
50 \\
- \\
45.5\end{array}$ & $\begin{array}{l}1 \\
2 \\
- \\
6\end{array}$ & $\begin{array}{c}5.9 \\
50 \\
- \\
54.5\end{array}$ & $\begin{array}{l}50 \\
6 \\
- \\
16\end{array}$ & -0.18 & & 0.02 \\
\hline Total & 23 & & 9 & & & & & \\
\hline $\begin{array}{l}\text { Slope class }(\%) \\
0-20 \\
20-40 \\
>40\end{array}$ & $\begin{array}{c}17 \\
3 \\
3\end{array}$ & $\begin{array}{c}85 \\
60 \\
42.9\end{array}$ & $\begin{array}{l}3 \\
2 \\
4\end{array}$ & $\begin{array}{c}15 \\
40 \\
57.1\end{array}$ & $\begin{array}{c}53 \\
9 \\
9\end{array}$ & -0.10 & & 0.18 \\
\hline Total & 23 & & 9 & & & & & \\
\hline $\begin{array}{l}\text { Forest type } \\
\text { Mixed deciduous } \\
\text { Dry dipterocarp } \\
\text { Dry evergreen }\end{array}$ & $\begin{array}{c}17 \\
3 \\
3\end{array}$ & $\begin{array}{c}80.9 \\
100 \\
37.5\end{array}$ & $\begin{array}{l}4 \\
0 \\
5\end{array}$ & $\begin{array}{c}19.1 \\
0 \\
62.5\end{array}$ & $\begin{array}{c}53 \\
9 \\
9\end{array}$ & & & \\
\hline Total & 23 & & 9 & & & & & \\
\hline
\end{tabular}

With respect to habitat types, salt licks, water sources, and active elephant trails were mainly found in mixed deciduous forest (53\%), rather than in dry evergreen forest $(9 \%)$ or dry deciduous dipterocarp forest (9\%) (Table 3, Fig. 1). The use of natural licks, waterholes, and wildlife trails did not differ among habitat types $(F=1.979$, df $=2, \mathrm{p}=0.14)$.

The RAI of elephants in the entire Salakpra Wildlife Sanctuary was 10.3 captures per 100 trap nights, with a relative frequency of $72 \%$ considering all camera trap sites. Elephants obtained the highest relative abundance at waterholes, and the relative frequency was highest in natural licks (Table 4).

Table 4. Relative abundance index (RAI) and relative frequency (RF) of wild Asian elephants Elephas maximus in Salakpra Wildlife Sanctuary, Thailand. 'Presence' indicates the no. of traps in which the elephants were photographed

\begin{tabular}{|lcccccc|}
\hline Type & $\begin{array}{c}\text { Total } \\
\text { (traps) }\end{array}$ & $\begin{array}{c}\text { Presence } \\
\text { (traps) }\end{array}$ & $\begin{array}{c}\text { No. trap } \\
\text { nights }\end{array}$ & $\begin{array}{c}\text { Encounter } \\
\text { rate }\end{array}$ & RAI & RF \\
\hline Waterhole & 7 & 7 & 293 & 56 & 19.11 & 22 \\
Salt lick & 11 & 10 & 540 & 67 & 12.41 & 31 \\
Wildlife trail & 14 & 6 & 558 & 20 & 3.58 & 19 \\
Total & 32 & 23 & 1391 & 143 & 10.28 & 72 \\
\hline
\end{tabular}

\section{DISCUSSION}

The Asian elephant population in the Salakpra Wildlife Sanctuary has increased from 20 and 35 individuals in 1987 and 1990, respectively (Dobias 1987, Santiapillai \& Jackson 1990) to 180 individuals in 2012 when this study was carried out. These findings are supported by Siripunkaw \& Kongrit (2005), who estimated a similar population size for our study area using a DNA analysis. The elephant density found in these studies was similar to that of the Khao Ang Rue Nai Wildlife Sanctuary (Wanghongsa et al. 2006) and the Bardia National Park in Nepal (Flagstad et al. 2012), but lower than in Huai Kha Khaeng Wildlife Sanctuary in Thailand (0.73 ind. $\mathrm{km}^{-2}$ ) (Sukmasuang 2003). According to the carrying capacity model of Sukumar \& Santipiallai (1993), elephant density may reach 0.2 to 0.3 ind. $\mathrm{km}^{-2}$, or 216 individuals in our study area. This may explain why some elephants go outside the Salakpra Wildlife Sanctuary due to the population exceeding the carrying capacity as Wanghongsa et al. (2007) suggested. However, the elephant density of Salakpra Wildlife Sanctuary surpasses the population limit suggested by the model. The number of elephants in Salakpra was also confirmed by closed captures in MARK 
(White \& Burnham 1999). Due to the short-term period of our study, the population size did not vary between sampling events, and there were no episodes of immigration or emigration.

The population structure of wild Asian elephant in the area consisted of mostly adult individuals, which agrees with the findings of Santiapillai et al. (1984). Obtaining this information was only possible because of the use of camera traps to identify the individuals and to classify their age and sex (see also Varma et al. 2006).

The population also consisted of more adult females than adult males; therefore, the probability of reproduction is high. Overall, the reproductive ratio of wild elephants in Salakpra Wildlife Sanctuary was relatively low compared to the findings of Katugaha et al. (1999) in Ruhuna National Park, Sri Lanka, and Siripunkaw \& Kongrit (2005) in our study site from several years prior to the present study. This is probably due to our inclusion of sub-adult females in the reproductive ratio calculation. Conversely, the reproductive ratio of adult females to calves was greater than for elephants in India (Choudhury 1999, Ramesh et al. 2012). This variability in population dynamics likely reflects differences in environmental conditions and carrying capacities between sites (Ramesh et al. 2012), such as salt licks in the Salakpra Wildlife Sanctuary. At any rate, our study shows a trend towards an increasing population of elephants.

Most elephants were found in the flat plains, which is consistent with the findings of other studies (Pradhan \& Wegge 2007, Varma 2008, Zhang 2011, Alfred et al. 2012), and also where most waterholes are located (Alfred et al. 2012). Elephants generally avoid feeding or walking in upland areas in order to save energy (Wall et al. 2006). We found that solitary male elephants appeared at higher elevations in dry evergreen forests to avoid conflict with the dominant males in the lowland areas. This finding is similar to that of Steinmetz et al. (2008), who found elephants in the hill evergreen forests above $1000 \mathrm{~m}$ in Thung Yai Naresuan Wildlife Sanctuary, Thailand, and that of Wanghongsa et al. (2006), Lin et al. (2008), Varma (2008), and Joshi (2009), who documented elephants in areas up to $1300 \mathrm{~m}$ above sea level. We established that elephants in the Salakpra Wildlife Sanctuary mainly used shallow slopes (0 to $20 \%$ ), a finding similar to other studies (Sukmasuang 2003, Lin et al. 2008). Mixed deciduous forest was the most suitable habitat for elephants in Salakpra Wildlife Sanctuary, since bamboo, a favorite food of elephants, is dominant in the area (Gray \& Phan
2011). Large food-plant productivity has been found to be positively related to utilization by wild elephants (Rood et al. 2010), and is a main factor affecting their seasonal movements (Lin et al. 2011).

Elephants were photographed more often at salt licks and waterholes compared to wildlife trails. Asian elephants rely on salt licks for nutrient supplementation (Moe 1993, Klaus \& Schmid 1998, Mills \& Milewski 2007) and alleviation of gastrointestinal disorders from toxic plant compounds, acidosis, diarrhoea, and endoparasites (Klaus \& Schmid 1998, Krishnamani \& Mahaney 2000). Most salt licks were located within relative proximity to streams or waterholes within mixed deciduous forest, with those closest to the waterholes being the most frequently visited. The principal factor determining elephants' use of salt licks and waterholes is thought to be the annual rainfall cycle; elephant movements are known to be strongly controlled by water availability, especially during the dry season (Smit et al. 2007, Chamaillé-Jammes et al. 2007, de Beer \& van Aarde 2008).

Our research indicates that the basic factors that are important to elephant populations are salt licks, waterholes, and food sources. In order to provide the most effective management of wild elephant populations, the following actions should be considered: (1) maintain shallow permanent waterholes; (2) maintain and monitor effective salt licks, measuring the minerals remaining in them, which will be beneficial for elephants as well as other wildlife; (3) increase potential food sources such as grassland areas and remove invasive exotic plants and weeds; and (4) re-establish foodplant species in disturbed areas.

\section{CONCLUSIONS}

Our study suggests that the 3 groups of elephants in the Salakpra Wildlife Sanctuary were distributed according to the presence of the same fundamental features: flat plains, low slopes, areas of mixed deciduous and dry dipterocarp forests (bamboo), waterholes, and salt licks. The RAI of elephants in this study was greater than that in other areas due to the high reproductive ratio. This indicates that the trend for the elephant populations in the Salakpra Wildlife Sanctuary is increasing. However, effective management strategies must be applied to ensure the long-term conservation of this and other Asian elephant populations. 
Acknowledgements. Thanks are extended to the Salakphra Wildlife Sanctuary, Department of National Parks, and the Wildlife and Plant Conservation for providing permission and assistance for data collection. Our appreciation and thanks to Antony J. Lynam, Wildlife Conservation Society, Global Conservation Program, Norberto Asensio, John Lawrence, and Steven Cochrane, Faculty of Environment and Resource Studies, Mahidol University, Thailand, for technical support and friendship. This project was funded by Mahidol University, Thailand.

\section{LITERATURE CITED}

Alfred R, Ahmad AH, Payne J, Williams C, Ambu LN, How PM, Goossens B (2012) Home range and ranging behaviour of Bornean elephant (Elephas maximus borneensis) Females. PLoS ONE 7:e31400

Arivazhagan C, Sukumar R (2008) Constructing age structure of Asian elephant populations: a comparison of two field methods of age estimation. Gajah 29:11-16

Ashokkumar M, Nagarajan R, Desai AA (2010) Group size and age-sex composition of Asian elephants and gaur in Mudumalai Tiger Reserve, southern India. Gajah 32: 27-34

Campos-Arceiz A, Blake S (2011) Megagardeners of the forest - the role of elephants in seed dispersal. Acta Oecol 37:542-553

Chamaillé-Jammes S, Valeix M, Fritz H (2007) Managing heterogeneity in elephant distribution: interactions between elephant population density and surface-water availability. J Appl Ecol 44:625-633

> Choudhury AU (1999) Status and conservation of the Asian elephant Elephas maximus in north-eastern India. Mammal Rev 29:141-173

de Beer Y, van Aarde RJ (2008) Do landscape heterogeneity and water distribution explain aspects of elephant home range in southern Africa's arid savannas? J Arid Environ 72:2017-2025

Della Rocca F (2007) How tall is an elephant? Two methods for estimating elephant height. Web Ecol 7:1-10

Dobias RJ (1987) Elephants in Thailand: an overview of their status and conservation. Tigerpaper 14:19-24

Feng L, Wang Z, Lin L, Yang S and others (2010) Habitat selection in dry season of Asian elephant (Elephas maximus) and conservation strategies in Nangunhe National Nature Reserve, Yunnan, China. Acta Theriol Sin 30: $1-10$

Flagstad Ø, Pradhan NMB, Kvernstuen LG, Wegge P (2012) Conserving small and fragmented populations of large mammals: non-invasive genetic sampling in an isolated population of Asian elephants in Nepal. J Nat Conserv 20:181-190

Goswami VR, Lauretta MV, Madhusudan MD, Karanth KU (2012) Optimizing individual identification and survey effort for photographic capture-recapture sampling of species with temporally variable morphological traits. Anim Conserv 15:174-183

Gray TNE, Phan C (2011) Habitat preferences and activity patterns of the larger mammal community in Phnom Prich Wildlife Sanctuary, Cambodia. Raffles Bull Zool 59: 311-318

IUCN (2013) IUCN Red List of Threatened Species, Version 2013.2. www.iucnredlist.org (accessed 22 Jan 2014)

Joshi R (2009) Asian elephant's Elephas maximus behaviour in the Rajaji National Park, north-west India: eight years with Asian elephant. Nat Sci 7:49-77

Katugaha HIE, de Silva M, Santiapillai C (1999) A long-term study on the dynamics of the elephant (Elephas maximus) population in Ruhuna National Park, Sri Lanka. Biol Conserv 89:51-59

> Klaus G, Schmid B (1998) Geophagy at natural licks and mammal ecology: a review. Mammalia 62:481-497

Kongrit C, Siripunkaw C, Brockelman WY, Akkarapatumwong V, Wright TF, Eggert LS (2008) Isolation and characterization of dinucleotide microsatellite loci in the Asian elephant (Elephas maximus). Mol Ecol Resour 8:175-177

Krishnamani R, Mahaney WC (2000) Geophagy among primates: adaptive significance and ecological consequences. Anim Behav 59:899-915

Lin L, Feng L, Pan W, Guo X, Zhao J, Luo A, Zhang L (2008) Habitat selection and the change in distribution of Asian elephants in Mengyang Protected Area, Yunnan, China. Acta Theriol (Warsz) 53:365-374

Lin L, Zhang LT, Luo AD, Wang LF, Zhang L (2011) Population dynamics, structure and seasonal distribution pattern of Asian elephant (Elephas maximus) in Shangyong Protected Area, Yunnan, China. Acta Theriol Sin 31: 226-234

> Lyra-Jorge MC, Ciocheti G, Pivello VR, Meirelles ST (2008) Comparing methods for sampling large- and mediumsized mammals: camera traps and track plots. Eur J Wildl Res 54:739-744

Matsubayashi H, Lagan P, Sukor JRA (2006) Utilization of macaranga trees by Asian elephants (Elephas maximus) in Borneo. Mammal Study 31:115-118

> Mills A, Milewski A (2007) Geophagy and nutrient supplementation in the Ngorongoro Conservation Area, Tanzania, with particular reference to selenium, cobalt and molybdenum. J Zool (Lond) 271:110-118

Moe SR (1993) Mineral content and wildlife use of soil licks in southwestern Nepal. Can J Zool 71:933-936

> Pattanavibool A, Dearden D, Kutintara U (2004) Habitat fragmentation in north Thailand: a case study. Bird Conserv Int 14:s13-s22

> Pradhan NMB, Wegge P (2007) Dry season habitat selection by a recolonizing population of Asian elephants Elephas maximus in lowland Nepal. Acta Theriol (Warsz) 52: 205-214

> Ramesh T, Sankar K, Qureshi Q, Kalle R (2012) Group size and population structure of megaherbivores (Gaur Bos gaurus) and Asian elephant (Elephas maximus) in a deciduous habitat of Western Ghats, India. Mammal Study 37:47-54

> Rood E, Ganie AA, Niiman V (2010) Using presence-only modelling to predict Asian elephant habitat use in a tropical forest landscape: implications for conservation. Divers Distrib 16:975-984

Rovero F, Marshall AR (2009) Camera trapping photographic rate as an index of density in forest ungulates. J Appl Ecol 46:1011-1017

Rowcliffe JM, Carbone C (2008) Surveys using camera traps: Are we looking to a brighter future? Anim Conserv 11:185-186

Rowcliffe JM, Field J, Turvey ST, Carbone C (2008) Estimating animal density using camera traps without the need for individual recognition. J Appl Ecol 45:1228-1236

Salakpra Wildlife Sanctuary (2011) Master plan of Salakpra Wildlife Sanctuary, Kanchanaburi Province B.E. Department of National Park, Wildlife and Plant Conservation, 
Protected Areas Regional Office 3 (Ban Pong), Ratchaburi, p 2554-2558 (in Thai)

Santiapillai C, Jackson P (1990) The Asian elephant: an action plan for its conservation. IUCN/SSC Asian Elephant Specialist Group, Gland

Santiapillai C, Chambers MR, Ishwaran N (1984) Aspects of the ecology of the Asian elephant (Elephas maximus L.) in the Ruhuna National Park, Sri Lanka. Biol Conserv 29: $47-61$

Sarker AHMR, Røskaft E (2010) Human-wildlife conflicts and management options in Bangladesh, with special reference to Asian elephants (Elephas maximus). Int $\mathrm{J}$ Biodivers Conserv 6:164-175

Silveira L, Jacomo ATA, Diniz-Filho JAF (2003) Camera trap, line transect census and track surveys: a comparative evaluation. Biol Conserv 114:351-355

Siripunkaw C, Kongrit C (2005) Estimation of population size and genetic diversity of Asian elephant by salt lick method at Salakpra Wildlife Sanctuary, Kanchanaburi province. Mahidol University, Nakhon Pathom (in Thai)

Smit IPJ, Grant CC, Devereux BJ (2007) Do artificial waterholes influence the way herbivores use the landscape? Herbivore distribution patterns around rivers and artificial surface water sources in a large African savanna park. Biol Conserv 136:85-99

Soisalo MK, Cavalcanti SMC (2006) Estimating the density of a jaguar population in the Brazilian Pantanal using camera-traps and capture-recapture sampling in combination with GPS radio-telemetry. Biol Conserv 129: 487-496

Srikrachang M (2003) Conservation and management of elephants in Thailand. PhD dissertation, Mahidol University, Bangkok

Steinmetz R, Chutipong W, Seuaturien N, Cheungsa-ad E (2008) Community structure of large mammals in tropical montane and lowland forest in the TenasserimDawna mountains, Thailand. Biotropica 40:344-353

Sukmasuang R (2003) Ecology and population density of Asian elephant in Huai Kha Khaeng Wildlife Sanctuary. J Wildl Thail 11:13-36 (in Thai)

Sukumar R (2003) The living elephants: evolutionary ecology, behavior, and conservation. Oxford University Press, Oxford

Sukumar R, Santipiallai C (1993) Asian elephant in Sumatra

Editorial responsibility: Nils Bunnefeld, Stirling, UK population and habitat viability analysis. Gajah 11:59-63

Varma S (2008) Spatial distribution of Asian elephant (Elephas maximus) and its habitat usage pattern in KalakadMundanthurai Tiger Reserve, Western Ghats, Southern India. Curr Sci 94:501-506

Varma S, Pittet A, Jamadagni HS (2006) Experimenting usage of camera-traps for population dynamics study of the Asian elephant Elephas maximus in southern India. Curr Sci 91:324-331

Wall J, Douglas-Hamilton I, Vollrath F (2006) Elephants avoid costly mountaineering. Curr Biol 16:R527-R529

> Wang SW, Macdonald DW (2009) The use of camera traps for estimating tiger and leopard populations in the high altitude mountains of Bhutan. Biol Conserv 142:606-613

Wanghongsa S (2004) Population number and structure of elephants in KhaoAng Rue Nai Wildlife Sanctuary, Chacheongsao, Sa Kaeo, Chantaburi, Rayong and Chonburi Provinces. Fakthong Graphics and Screen, Prachinburi (in Thai)

Wanghongsa S, Senatham Y, Boonkird K, Saengsen D (2006) Why do elephant bulls wander outside forest areas of Khao Ang Rue Nai Wildlife Sanctuary? Wildl Yearb 7: 156-169

Wanghongsa S, Boonkird K, Saengsen D, Jantarat N (2007) Monitoring of elephant population dynamics in Khao Ang Rue Nai Wildlife Sanctuary. Report of the Forest and Plant Conservation Research Office, Department of National Parks, Plant Conservation, Bangkok, p 398-412

WEFCOM (Western Forest Complex) (2004) GIS database and its applications for ecosystem management. Department of National Park, Wildlife, and Plant Conservation, Bangkok

> White GC, Burnham KP (1999) Program MARK: survival estimation from populations of marked animals. Bird Study 46:S120-S138

White GC, Anderson DR, Burnham KP, Otis DL (1982) Capture-recapture and removal methods for sampling closed populations. Los Alamos National Laboratory Publication LA-8787-NERP, Los Alamos, NM

World Wildlife Fund (WWF) (2006) Species fact sheet: Asian elephant. http://assets.panda.org/dowmloads/asian _elephant_factsheet2006.pdf (accessed 10 Nov 2015)

Zhang L (2011) Current status of Asian elephants in China. Gajah 35:43-46

Submitted: April 13, 2015; Accepted: October 8, 2015 Proofs received from author(s): November 11, 2015 